Article

\title{
Towards A New Reading of the Political Thought of the Dévot Faction: The Opposition to Cardinal Richelieu's Ministériat
}

\section{Caroline Maillet-Rao}

Campus Saint-Jean, University of Alberta, 8406, rue Marie-Anne Gaboury (91 St) Edmonton, AB T6C 4G9, Canada; E-Mail: mailletr@ualberta.ca; Tel.: +1-780-435-2102

Received: 27 September 2013; in revised form: 23 October 2013 / Accepted: 25 October 2013 / Published: 31 October 2013

\begin{abstract}
For a long time, historiography has considered the political thought of the dévot party, led by Mathieu de Morgues and Michel de Marillac, to be supportive of a traditional monarchy, Catholicism and the extermination of Protestants, while being opposed to the Thirty Years War. This faction's political thought has been looked upon as being in contrast to that of Cardinal Richelieu, which was comparatively regarded as profoundly absolutist and modern. Such an understanding of the dévots' political thought, albeit disputed, continues to prevail. The present article intends to demonstrate that the dévots were in fact on the side of the absolutists, which explains their opposition to Richelieu. Indeed, they never criticized absolutism, but rather, the illegitimate leadership of the government by an all-powerful premier ministre, namely, Richelieu. According to the dévots, the ministériat actually betrayed the very essence of absolute monarchy. Before proposing a new perspective on its political thought, it is important to reflect upon the definition of the dévot party. This will be followed by an overview of the lives and work of the principal representatives of this faction, Mathieu de Morgues (1582-1670) and Michel de Marillac (1560-1632). An examination of the historiography on this subject enables this article's conclusions to be situated in a broader context.
\end{abstract}

Keywords: dévots; absolutism; ministériat; Mathieu de Morgues; Michel de Marillac; Richelieu

\section{Introduction}

The political thought of the dévots is the subject of new interpretations that do not, necessarily, invalidate those that predate them, to the extent that today, it is nearly impossible to determine whether 
the dévots are to be viewed as bons français or bons catholiques. Opposed to the bons français or the étatistes, which is to say Cardinal Richelieu's partisans, the bons catholiques or dévots were always reputed to be at once ultramontane, pro-Spanish and in favour of a limited monarchy [1-11]; this despite the fact that certain works highlight Marillac's absolutism ([2], pp. 1-24; [12-16]) and the Gallicanism of Mathieu de Morgues, which was demonstrated in the events surrounding the 1621 condemnation of Bellarmin [17,18]. Whereas the cardinalists, heirs to the Politiques, are presented as Gallicans, hostile to the Hapsburgs and the Spaniards, and in favour of the emerging absolute monarchy, the interpretation of the distinction between the dévots and Cardinal Richelieu's party continues to find acceptance for two reasons. First, because Mathieu de Morgues is still seen as being opposed to the implementation of the absolute monarchy ([1], pp. 167-78; [11], pp. 179-212; [13], p. 669; [17], pp. 453-54; [19]) and, second, because the relevant foreign policy criterion presenting the dévots as being pro-Spanish was never repudiated. On the contrary, the most recent works pertaining to the dévots made much of the idea that when it came to foreign policy concerns, Marillac was opposed to any war with Spain and the House of Austria, as his intent was to defend the interests of Catholicism to the detriment of those of the State ([2], pp. 1-24; [10], pp. 49-69). These works end up validating the thesis of Georges Pagès, who thus remains the accepted authority on the subject.

The analysis of the historiography pertaining to the political thought of the dévots ultimately indicates the necessity of re-examining the question as a whole, because the dévots' political thinking is far from incoherent. Nor are the aforementioned criteria misplaced when it comes to distinguishing good Catholics from good Frenchmen. However, one more should be added: the position of the political actors towards the ministériat during the reign of Louis XIII. In fact, the recent works that underline Marillac's absolutism illustrate that the differences between the political thought of the dévots and that of Richelieu were not nearly as radical as the relevant historiography has made them out to be. These studies have insisted on the points of convergence between the two parties. Continuing in this vein, if one had to situate the dévots, it would be on the side of the good Frenchmen, as much with regards to their position on the monarchy, as on the Church or matters related to foreign policy. It is clearly possible to maintain that the dévots' opposition to the cardinal was not based on the defence of a traditional monarchy, but, rather, on their opposition to the appointment of a principal ministre ${ }^{1}$.

Before detailing this study's view of the dévots' political thought, it is worth reflecting upon a definition of the dévots; this will be followed by an examination of the life and work of those who clearly appear as the representatives of the dévot party: Mathieu de Morgues and Michel de Marillac. This, in turn, will be followed by an analysis of the historiographies in order to contextualize any conclusions.

\section{The Dévot Party Represented by Mathieu de Morgues and Michel de Marillac}

The dévots are traditionally depicted as opponents of Cardinal Richelieu's political activities. The Day of the Dupes or "Grand orage” ${ }^{2}$ marked the end of the dévot party's influence in France, but not

1 This thesis, defended in November, 2004 at the Université de Tours, has been submitted by Caroline Maillet-Rao for publication under the title: La pensée politique des dévots Mathieu de Morgues et Michel de Marillac: une opposition au ministériat du Cardinal de Richelieu. cf. [20,21].

2 "Journée qui a fait la France" according to the expression by Georges Mongrédien, the Day of the Dupes is the day when King Louis XIII finally decided to confirm Richelieu as principal ministre and to oust his opponents on the 
the end of its activity, as the dévots in exile continued to protest and to denounce the cardinal's stranglehold on French political life. Mathieu de Morgues and Michel de Marillac are known as the fiercest opponents of Louis XIII's principal ministre. However, the characterization of the dévots remains vague, because there are other important individuals associated with them, individuals who were not involved in the influential circles surrounding Louis XIII. As William Beik has recently underlined, several groups are included in the designation dévot ${ }^{3}$. Thus, it is important to clearly indicate which group of dévots is being referred to, as they did not all share the same point of view, differing as they did according to time period, social conditions, the context of their actions, etc. The all-encompassing definition of the dévots was initially influenced by two major works, the first of which was Histoire littéraire du sentiment religieux by the abbot, Henri Brémond. In it, Brémond describes the dévots as those who attended to their devotions and gathered about the 'Bienheureuse et vénérable Mère' Madeleine de Saint-Joseph at the Hôtel Acarie, amongst whom were Michel de Marillac, Pierre de Bérulle, Saint François de Sales, Saint Vincent de Paul [33]. Brémond describes the dévot circle, not the dévot party. The second of these works was Étienne Thuau's Raison d'Etat et pensée politique à l'époque de Richelieu [34]. The dévots are treated in this work as a school of thought, whose founding principle is devotion. Thus, the dévots' political thinking fits into the school considered to be opposed to the reason of state ([34], 103-152). It presents Mathieu de Morgues and Michel de Marillac as emblematic figures of the dévot party, the former as the spokesperson for Marie de Medici and the latter as the successor to Cardinal de Bérulle as the head of the party. It is important here to clearly distinguish between these groups, as it appears to this observer that Pierre de Bérulle was not the leader of the dévot party, but that of the circle of dévots. Stéphane-Marie Morgain's research supports this: the life of Cardinal de Bérulle was not so much political as it was religious; and his political theology did not lead to much involvement in politics ${ }^{4}$ ([10], p. 52; [35]). The principal

council, the dévot party. This occurred on November 11, 1630. There are several versions of what took place that day, but it is the version from the winning side, the one related in Richelieu's Memoires, which entered into the annals of history. The dévots' version, depicted by Mathieu de Morgues, was relegated to history's dust bin. This is a subject for analysis in a future publication. As for the official version, it recounts that it all began with the Queen Mother's desire to rid herself, once and for all, of the "insolent" Cardinal Richelieu. In the company of her son Louis, behind closed doors in her office in the Palais du Luxembourg, Marie attempted to convince the king to dismiss the troublesome minister. However, Richelieu suddenly entered into the room through a small door, which had gone unnoticed by the Queen Mother. Beside herself, Marie de Médicis insulted the cardinal, who burst into tears at the foot of the king. Exhausted by these veiled, internecine struggles, Louis XIII took leave of his mother with a bow, without acknowledging the cardinal. Believing himself abandoned, a distraught Richelieu thought to flee. The Queen Mother appeared triumphant before the court and entrusted de Marillac, her faithful supporter and garde de sceaux, with the formation of the new government. On the pretext of a hunting expedition, the king travelled to Versailles, where he finally decided to summon his minister. The subsequent interview re-established his confidence in Richelieu. The cardinalist version of the Day of the Dupes is also used in historical novels ([4], pp. 379-401; [5], pp. 65-70; [10], pp. 61-62; [19], p. 63; [22-31]).

3 In this sense, $c f$. William Beik, which gives an overview of the different circles of dévots appearing under the Catholic Reformation [32].

4 I must indicate that these conclusions are not those of Morgain, but rather, the results of my own interpretation. On the contrary, the author considers Bérulle as one of the leaders of the dévots along with Marillac, even if he admits that Bérulle was less willing to combine religious life with political ambition. 
means to determine who was a member of the dévot party should be evidence of political action. As Jean-Pierre Gutton maintains in his latest work, Dévots et société au XVII siècle, the circle of dévots is to be understood more socially and the dévot party more politically [36]. At the end of the sixteenth century, a circle of dévots formed within the confines of the old Ligue party. Wishing to pursue the restoration of Catholicism and influenced by the Christian humanism of the Jesuits and Spanish mysticism, these dévots withdrew from the field of political action and sought to attain Christian perfection. They would meet, notably, at the residence of Madame Acarie (1566-1618), who was establishing a Carmelite monastery in France. Certain members of Madame Acarie's circle were to be found with those surrounding Marie de Médicis. Thus, the dévot circle and the dévot party, which arose from the former, mingled at the court of the Queen Mother. However, the dévot party is clearly the group more inclined to political, rather than social, issues and, in one way or another, shared the political life of the Queen Mother Marie de Médicis. Thus, the dévot party was originally formed from the Queen Mother's political advisors. It appears to have united those who preferred political action to charitable works, contemplation or the apostolate. If it is clear that Morgues and Marillac both came from this circle of dévots and were its successors, they chose to enter the realm of politics, thus relegating the contemplative and apostolic life to the background. This is an essential distinction, as diving into the political reality of the members of the dévot party led some to revise, to adapt or go beyond certain inherited ideas that could no longer be defended in the same way. While the thinking of the members of this circle of dévots continued to develop through access to the ideological apparatus of the Ligue from which they had descended, the members of the dévot party saw their ideas evolve in the direction of absolutism. This explains why Michel de Marillac and Mathieu de Morgues adopted positions favouring the implementation of the absolute power of the king.

On this subject, the reasoning of Françoise Hildesheimer concerning the dévot party is notable. Firstly, the historian notes that "les Catholiques zélés" within the circles of Marie de Médicis and Cardinal Richelieu had aligned themselves with the "Catholicisme d'État" following the affair of State Santarelli ([26], pp. 85-122; [37]). Therefore, the author insists that "Le monde des dévots doit être redéfini en fonction de ces critères nouveaux qui sont ceux d'une modernité politique émergente.” This is why she distinguishes the dévot party "qui mériterait plus d'être appelé le parti de la reine mère" from the other party, more commonly known as Les politiques, which she looks upon as being dévot. According to her, the first is politically embodied by Marillac and characterized by its fear of the domestic consequences resulting from Richelieu's foreign policy. While the second, which is comprised of “catholiques tout aussi zélés que le premier”, had learned from the French experience of the religious wars and the Empire's current situation ([25], pp. 236-37). Hildesheimer's original analysis of the dévot party emphasizes that Catholics, Richelieu and his circle had further developed ideas inherited from the League to adapt to the needs of the present. Her conclusion regarding Richelieu and his circle is in line with that of this article regarding Mathieu de Morgues and Michel de Marillac. Consequently, there is little doubt as to the origin of the confusion on the dévots' political thought, a confusion mainly stemming from the fact that historians opposed this new vision of Richelieu's political approach to that of "Bérulle et les dévots"5([24], p. 736). Yet, how similar was the

5 Jean-François Dubost, as Françoise Hildesheimer, and mostly all historians considered that Bérulle and Marillac shared the same vision. 
political thought of Bérulle and Marillac? Were the policies advocated by the Queen Mother and Michel de Marillac really based on Berulle's political theology? If so, how does one account for the fact that the Queen Mother favoured France’s entering into war against Spain in $1630^{6}$ ([4], p. 120; [24], p. 773)? How it is that Marillac also endorsed such a position? By examining the political thought of Mathieu de Morgues and Michel de Marillac, it becomes apparent that they too had adapted their political ideas to the context of their time. From our point of view, the opposition between the two circles was not so much based on political orientation, but rather, on Richelieu's desire to reduce the triumvirate to the ministériat.

Regarding Pierre de Bérulle, Stéphane-Marie Morgain argues that the cardinal was ultramontane, hostile to any conflict with Spain and in favor of a restoration of the kingdom through the eradication of the Protestant heresy. Morgain also equates Bérulle's policy to that of Marillac and the dévots in general ([35], p. 58). In light of the favorable positions taken by the Queen Mother and Michel de Marillac to the military intervention in Casal, is it possible that Bérulle was isolated in the Queen Mother's party and that his political approach was not adopted by Marie de Médicis and Marillac? In this case, it would seem necessary to distinguish between the group led by Bérulle defending ideas inherited from the League ${ }^{7}$ ([35], pp. 91-109, 395) and the group headed by Marillac, which brought together dévots who had adapted their ideas to the needs of the time. When one claims that Bérulle was promoting the ideas of the League, one need not mean that he was a partisan of a moderate monarchy. Quite the contrary, Bérulle was in favor of a type of absolutism described as “intransigent” by Jean-François Dubost, which was, as demonstrated by Stéphane-Marie Morgain, based on a unitary conception of the monarchy. It is precisely this vision of power that justified his political position against Protestants ([24], 704-23; [35], pp. 281-385). From one angle, this is his main difference with Marillac: if his absolutism was also inflexible, it had not led him to defend the eradication of Protestants. Given the failure of the wars of religion, he was convinced that the policy of tolerance adopted by the Edict of Nantes was more effective. Marillac's uncompromising absolutism led him to oppose the ministériat. Since there are questions yet to be answered concerning Bérulle's political approach and considering the differences that appear between the thought of Berulle and Marillac, one need not equate them.

Party members were devout individuals from within the circle of Mme Acarie who wished to play a political role alongside Marie de Médicis. However, it is important to keep in mind that Richelieu was the main leader of the Queen Mother's party up until their rupture in 1628. Michel de Marillac also played a significant role as demonstrated firstly by his appointment as Superintendent of Finances in 1624, a few months after Richelieu became a member of the council, and then as garde des sceaux in 1626. Thus, between 1626 and 1628, Marillac was the fourth most influential figure in the kingdom, after Louis XIII, Marie de Médicis and her créature, Richelieu. As Marie de Médicis’s confessor, Bérulle was also an influential figure. As for Mathieu de Morgues, he defended the political party's line in his pamphlets. Close to Marie de Médicis, he was first employed by Richelieu in his "atelier

6 Jean-François Dubost as Jean-Vincent Blanchard notes that Marie de Médicis supported the war without really explaining: "Did she realize that nothing could change her son's determination, and that she risked alienating him if she kept on with her steadfast refusals? Her motivations at this point remain obscure”.

7 Stéphane Marie Morgain asks the same question. 
d'écriture”. On the Day of Dupes, he claimed to have been "le seul avocat” [38] of the Queen Mother. Despite the lack of attention given to their political thought, Marillac and Morgues nonetheless left an important legacy to the political and institutional history of France by formulating and disseminating a thought equally as pragmatic as that of Richelieu.

Mathieu de Morgues came from a dévot background as he was the son of a ligueur, Claude de Morgues, who was a member of the petite noblesse provinciale. He completed his studies at the Jesuit college in Avignon and resolved to join the clergy. He thus became a novice and, after having attained a doctorate in theology, held a chair in their college. Yet, Morgues did not intend to become a Jesuit. In 1609, he decided to quit the Société de Jésus without obtaining the necessary dispensations. This departure foretold how he would distance himself from the ideas of his original surroundings. At the age of twenty-eight, in order to dedicate himself to the Catholic Reformation, Morgues chose the political approach and moved to Paris. Far from abandoning the clergy, he continued his studies and became a private tutor. Two years later, he received Holy Orders and was appointed priest to the parish of Aubervilliers. He enjoyed such success with his preaching that he drew the attention of Queen Marguerite de Valois (1553-1615), who engaged him in the role of predicateur ordinaire in 1613. During the two years that he attended upon her, Morgues spent time at the mansion she built near the Pré au Clers, which was frequented by Saint Vincent de Paul, the historian Scipion Dupleix and Jean Sirmond, future cardinalist writers whom Morgues would eventually oppose. In 1615, with the death of Queen Margot, Morgues became prédicateur ordinaire to the king. Up until 1617, he kept his distance from the parties. Before being appointed by the Queen Mother Regent Marie de Médicis as her prédicateur, and he began his duties as a pamphleteer ${ }^{8}$. Morgues remained attached to Marie de Médicis until the end of her life. He began by collaborating with Richelieu, then the Queen Mother's personal advisor prior to the definitive split that occurred with the Day of the Dupes. Found guilty of crime de lèse-majesté divine et humaine for "avoir formé des cabales contre le roi et fait des pratiques pour entreprendre sur la vie du cardinal de Richelieu son principal ministre” [39], Morgues was obliged to follow the deposed queen into exile. Thus began the famous pamphlet war waged by Mathieu de Morgues from Anvers. It was only after the death of the principal ministre that he was allowed to return to France to spend the remainder of his life at the Hospice des Incurables, where he had built a house.

Despite everything that could be said about his thinking, it was always guided by the defence of the divine right of kings. His choices, his battles and, mainly, his opposition to Cardinal Richelieu were based on his profound attachment to the absolute monarchy. His numerous pamphlets, most of which are compiled into two collections [40] covering some one thousand pages, all rigorously extol the same idea: only the absolute monarch is able to govern in such a way as to establish God's kingdom on Earth. One can therefore understand his defection from the Jesuits, who supported the indirect temporal power of the pope, which had led to the assassination of two kings, Henry III in 1589 and Henry IV in 1610. His opposition to the Jesuits' widespread doctrines was the subject of his pamphlet Antirrhopon ou Contrepoids aux jésuites et aux ministres de la religion prétendue réformée [41]. One

8 The first of Mathieu de Morgues's pamphlets, entitled Déclaration de la volonté de Dieu en l'institution de l'Eucharistie contre les erreurs de Pierre du Moulin, ministre de la R. P. P., Paris, 1617, published avec privilège du roi and approved by the Doctors in the Faculty of Theology of Paris (confirmed by J. Messier and C. Bazot). 
can equally understand his "acharnement" when faced with a principal ministre who, in accordance with his theory of the ministériat, exercised too much power in the eyes of Morgues and many of their contemporaries. Consequently, if his political actions took the form of pamphlets, it did not lessen their ideological or theoretical value. In the sixteenth and seventeenth centuries, the use of pamphlets was not limited to polemics or defamation ${ }^{9}$ [42-45]. History should not judge Morgues on the form in which his work appeared ([1], p. 178; [11], p. 185; [13], p. 289; [34], p. 128-29; [46,47]).

A descendant of one of Auvergne's old families, Michel de Marillac was first and foremost a mystic. Indeed, he wished to embrace the life of the clergy. Having been dissuaded from doing so by his tutor, he chose public office and first became maître des requêtes, then a state councillor. In 1624, when Marie de Médicis had become the most important advisor to the Council, she obtained the king's promotion for two of her creatures: Richelieu in the Royal Council and Marillac as Superintendent of Finance. In 1626, he was appointed garde des sceaux, a position he held until November 12, 1630, the day after the Day of the Dupes. Older than Mathieu de Morgues, Marillac took part in the Ligue, but his position already reflected the political line he would later adopt. His justification for his involvement in the Ligue française was that it alone advocated for the accession of a Catholic king of France [48]. His responsibilities reinstated after order was restored, he maintained his official career without turning away from his spiritual life, as indicated by his spiritual friendships with Madame Acarie and Mère Madeleine de Saint-Joseph. This was further demonstrated by the quasi-monastic manner in which Marillac spent his captivity, completely absorbed in spiritual reflection. There seems little evidence that he was close to his niece, Sainte Louise de Marillac (1591-1660) ([2], pp. 1-24; [10], pp. 49-69; [12], pp. 170-89; [49-55]).

Yet, in addition to this life as a dévot, which will forever rank him amongst the mystics of his day ([33], pp. 191-262; [56]), Michel de Marillac invested a great deal of himself into the political life of his time. Appearances to the contrary, his actual deliberations did not culminate in the Code Michau [57], an ordinance he had prepared as a garde des sceaux. The preparation of that edict led to the development of his conception of the State by means of three treatises that, to this day, remain unpublished. In the tradition of the Great Ordinances of reform, the one implemented in January of 1629 adopted a series of administrative measures ${ }^{10}$ aimed at ensuring that subjects obediently conformed to the conception of the State formulated in these three treatises. One deals with the attitude to adopt in front of parliamentary resistance [58], the second with the role of the Royal council [59]

9 The Dictionnaire de Furetière defines the pamphlet as written work that contains insults, criticism and accusations against someone's honour or reputation. The Dictionnaire de l'Académie française, p. 336, underlines that this word "se prend souvent en mauvaise part." The Dictionnaire historique de la langue française, p. 1411, defines it as a "petit ouvrage de circonstance d'esprit satirique ou polémique" and, associated in French, to an aggressive and violent tone.

10 Comprising 462 articles, the ordinance dealt with the right to the protest of parliaments and independent courts (article 1); clerical matters and ecclesiastical jurisdiction (article 2 to 58); clandestine marriages between strangers (article 39 and 40); the administration of hospices and the policy on beggars (article. 41 and 42); the privileges of universities and regulations of the printing press (article 43 to 52); the administration of justice (article 53 to 123); civil law, donations, inheritance, transfers and bankruptcies (article 123 to 169); criminal law, prohibited weapons, illegal organizations, privileges of the nobility, corruption in appointed office, hunting offences and military police (article 179 to 343); taxes, accounting officers, repurchase of property estates and diverse dispositions (article 344 to 429); admiralty, navy and maritime law (article 430 to 462). 
and the third with the function of the chancellor [60]. These documents reveal his conception of absolute monarchy. The analysis of these treatises, as well as other discourses and opinions, enables one to identify an absolutist vision of the monarchy, based on his opposition to the principal ministre. Marillac and Morgues found themselves in the circle surrounding Marie de Médicis and enlisted their talent with the written word in the fight to establish a genuine absolute monarchy, in which power would be vested solely in the king, to the exclusion of any other institution or advisor. Richelieu was equally in favour of the establishment of absolute monarchy. However, this did not detract from his role as the standard-bearer for the establishment of a new institution: that of a principal ministre who, at the pleasure of the king, could be vested with regal powers. In the eyes of the dévots, this theory was intolerable, as it did not stem from the divine rights of kings. It is precisely this opposition to the imposed ministériat that characterized the dévot party represented by Mathieu de Morgues and Michel de Marillac $^{11}$ ([1], p. 175).

\section{The Historiographical Point of View on the Political Thought of the Dévots}

Georges Pagès’s article “Autour du Grand Orage. Richelieu et Marillac: deux politiques” ([19], pp. 63-97), which appeared in 1937 in the Revue historique, remains the authoritative reference on the subject of the dévots' political thought, even if the argument it advances has been contested ${ }^{12}$ [61,62]. All the works devoted to the institutions and the politics of the first half of the seventeenth century present the dévots according to the terms set out by Pagès; as for current works specifically devoted to the dévots, they mainly resort to similar arguments. Pagès's contribution has been to affirm that the Grand Orage or journée des Dupes, which forced the king to choose between his mother and the cardinal, was not the result of conflicting ambitions, as was believed, but was rather the consequence of a clash of two irreconcilable policies in 1630. Thus, according to Pagès, the dévots became the defender of the traditional monarchy, which was opposed to the advent of modernity and the absolutism embodied by Richelieu. Pagès's work had a major impact on the historiography of the modern period. He remains the authoritative source, even if today, some of his ideas are outdated: for example, Marillac's preference for the traditional monarchy. Moreover, for many contemporary scholars, Marillac's absolutism and Morgues's Gallicanism are exceptions to the rule that the dévots were partisans of the traditional monarchy. There is little attempt to explain the discrepancy by exploring hypothesises other than those put forward by Pagès. For example, Seung Hwi Lim presents Marillac's absolutism by repeating most of what Pagès contends, and as the results are contradictory, concerning whether the dévots were good Catholics or good Frenchmen, Lim cannot but leave the question unanswered ([6], pp. 655-72).

In his work, Raison d'Etat et pensée politique à l'époque de Richelieu, published in 1966, Étienne Thuau followed Pagès as the authority on the subject [34]. His work is rooted in that of Friedrich

11 The position adopted by the author, Laurent Avezou, in interpreting the thought of Mathieu de Morgues is in line with that of the historiography. He nevertheless notes that Hay de Chastelet replied to Mathieu de Morgues with "une justification absolue du ministériat.” This comment points in the same direction as this article's interpretation of the dévots political position as being one of opposition to the ministériat as a new institution introduced by the cardinal within the framework of the monarchy.

12 A thesis refuted by François Olivier-Martin and by Robin Briggs. 
Meinecke's L'idée de la raison d'Etat dans l'histoire des temps modernes [63]. Beginning with Meinecke and up until the 1980s, the basic premise for understanding the politics of the first half of the seventeenth century was to associate absolutism and the advent of the secular State, the politics of which were no longer based on moral and religious considerations, but on reasons of State. Thus, during the reign of Louis XIII, there were different political movements, one of which Thuau described in the following manner: the cardinalistes, members of Richelieu's circle, partisans of the absolute monarchy, modernity and a secular State based on reason of the State that called upon Machiavelli. Thuau opposed them to the dévots, members of Marie de Médicis's circle and defenders of a limited, thus, traditional monarchy, whose political orientations were decided upon in light of religious considerations, which could sometimes conflict with the interests of the State.

The 1980s marked a turning point of significant historiographical importance: the reassessment of the hypothesis concerning the laicization of political thought. Until then, it was assumed that at the beginning of the seventeenth century, the State did not undertake laicization, but rather, secularization. Thus, the royalty freed itself from the influence of the Church, while continuing to make political decisions that conformed to religion. Indeed, Joël Cornette returned to the idea "d'un pouvoir politique soudain libéré de toute attache religieuse", not wanting to conclude "trop vite à une quelconque laicisation". Jean-François Courtine has openly criticized Thuau's thesis, in maintaining that modern-classic political thought does not find "son point de départ dans un processus général de laïcisation tendant à l'autonomisation du politique par rapport aux domaines antérieurement mal différenciés de l'ecclésial ou du théologico-politique”. Françoise Hildesheimer contested the "analyses trop superficielles" that concluded that power had been secularized in the seventeenth century and maintains that to "découper un objet État défini selon nos critères contemporains, réduit au domaine laïc, est un anachronisme qui réduit la religion au sacré, et l'État au profane en faisant fi du lien organique qui unit le pouvoir au sacré”. While Fanny Cosanday and Robert Descimon refuted the analyses of Thuau and Gérard Mairet, finding themselves in the postface of the republication of Thuau's book on the laicisation of power at the beginning of the seventeenth century, by way of critiques of Church and Courtine [64-67]. The power of the monarch remained subject to religion, firstly, because it existed by divine right. Moreover, the doctrine of divine right had not only been a theory aimed at protecting all of the king's current powers, but had created a veritable obligation for the king to govern according to God's will and to ensure that justice reigned on Earth. This profound reassessment led to another: that of Richelieu's political thinking. The common representation of the Machiavellian Richelieu has been dismantled. Several researchers have demonstrated the essential role that Christian principles played in Richelieu's political activities ([15], p. 324; [68-75]). Among these works completed over the last few years is a book entitled Richelieu et l'Église published in 2007 by the distinguished Jesuit professor, Pierre Blet [76]. Blet depicts a Richelieu devoted to the Church and conducting a political life according to the wishes of the pope. Thus, in addition to being the principal ministre, he was the "first ecclesiastic of France" in the words of Nuncio Scotti, the representative of the Holy See at the time of Richelieu. This book is exceedingly interesting in terms of explaining on what Richelieu's political policies were based. Nevertheless, the dévots are still portrayed as "partisans à tout prix de l'accord avec l'Espagne”, a description taken from Richelieu's writings ([76], p. 113). However, one can hardly hold this against the author, as it is not the subject of his book. Pagès's work had a major impact on the historiography of the modern period. His works remain the authoritative 
source on the matter, even if today, some of his ideas are outdated and Marillac's absolutism is acknowledged.

Studying Marillac’s early career, Russel Major was the first historian to demonstrate his absolutism. The garde des sceaux is even seen as more absolutist than Richelieu himself in the sense that Marillac tried to build a centralized and absolute $\operatorname{state}^{13}$ ([16], p. 619; [77]). Donald Bailey fully agrees: he explains Marillac's absolutism by way of his personal rigour and religious scruples. In Bailey's work, absolutism and religion are reconciled, thus allowing the très dévot Marillac to be seen as a supporter of absolute monarchy ([2], pp. 1-24; [3], p. XLV; [12], pp. 170-89). Robin Briggs has also questioned Georges Pagès's thesis relativizing complaints expressed by Marillac in his letters to Richelieu on the possibility of France re-entering the war against Spain in the early 1630s, seeing these complaints as the formulation of a simple apprehension of the consequences to the French people rather than a true political position ([62], pp. 71-92). As a result, the Anglo-American historiography has proposed an updated interpretation of Marillac's absolutism. A number of French historians have also recognized it, describing it as dévot to emphasize its specificity ([13], pp. 389-458; [14], p. 55; [15], p. 326; [56], p. 107). These studies thus concur in acknowledging Marillac's absolutism, at least up until the war against Spain. When France had to decide whether or not to enter into that war, all historians unanimously conclude that the dévots returned to the defense of traditional monarchy in order to maintain Christian unity, advocating for peace at any price and the eradication of the Protestant heresy ([1], p. 175; [11], pp. 194-95). Due to this interpretation, henceforth referred to as the théorie du revirement (reversal theory), historiography remains faithful to Georges Pagès, which creates an inconsistency on the question of absolutism.

In light of this blatant contradiction, I have endeavored to review this interpretation as a whole. For this purpose, the works of Robert Knecht and Françoise Hildesheimer both proved very useful. Studying the rise of Richelieu, they explain that Richelieu became a member of the Royal Council with the support of the influential Marie de Médicis. From this moment on until 1628, Louis XIII, the Queen Mother and her créature, Richelieu, formed a triumvirate: a kind of government in which Marie de Médicis and the Cardinal were the principal advisors to the king. Over the years, Richelieu slowly distanced himself from Marie de Médicis. In 1628, following the siege of La Rochelle, Richelieu celebrated his military triumph and, perhaps, his independence from his former protector. On a political level, Richelieu's autonomy vis-à-vis the Queen Mother had the effect of transforming the mode of government. The triumvirate evolved into a ministériat, a government comprised of the king and his chief minister, thereby leaving Marie de Médicis and her entire circle powerless ([8], pp. 34-35; [25], p. 234). From this perspective, any opposition during the Day of the Dupes could very well be seen as opposition to the ministériat. Furthermore, a new vision of the dévots' opposition to Richelieu was recently advanced by Jean-François Dubost in his monumental biography of Marie de Médicis. In one sense, his analysis supports my interpretation by showing that during her regency, Marie de Médicis promoted a reform of the monarchy that consisted of establishing a monarchie

13 Major's thesis has been contested by Richard Bonney, who claims that "there is no contemporary evidence apart from a claim made by Marillac's opponents after his arrest that the keeper of the Seals had such an intention (to want a centralised, absolute state administration) and sought to weaken the power of provincial estates by the introduction of elections". 
dévote, which is to say, a French confessional State in which the king's sacred status was reconfirmed with the vision of the absolutists. Marie de Médicis also educated her son in such a manner ([24], pp. 450-71). This certainly explains why Louis XIII had such high esteem for his dignity and his royal functions ([5], p. 54; [9]). This would also explain why Marie de Médicis could not support the ministériat, as the king was not the sole governing authority. For Dubost, the dévots'absolutism was "intransigent" and opposed to Richelieu's more pragmatic version ([24], p. 709). It is this opposition that would cause the breakdown of November 11, 1630 ([24], pp. 735-43). I agree completely with Dubost's conclusions as I believe that the Day of the Dupes showed the contrast between these two forms of absolutism. However, the author does not conclude that the dévots' opposition to Richelieu focused on the ministériat and, actually, he finally agrees with the reversal theory. Drawing on indirect sources, such as les Mémoires de Fontenay-Mareuil et de Brienne, he reverts to the idea that Bérulle and Marillac defended peace at any price, the eradication of Protestantism and the focus on internal reform ([24], pp. 752-59). However, he also believes that these political positions were based on the promotion of the monarchie dévote, which is absolute. Hence, Dubost manages to reconcile Pagès's conclusions and absolutism. While this is certainly a legitimate option, critical analysis of Mathieu de Morgues and Michel de Marillac's writings leads me to question these ideas and to propose an alternative interpretation of the dévots' opposition to the Cardinal. Moreover, my interpretation finds direct resonance in works, such as those by Jean-François Dubost, Robert Knecht and Françoise Hildesheimer, and is in line with the works of Russel Major and Donald Bailey.

\section{A New Vision of the Political Thought of the Dévots: An Opposition in All Respects to the Ministériat ${ }^{14}$}

The doctrines of Mathieu de Morgues and Michel de Marillac constituted a political opposition in all respects to the new system of ministerial government conceived by Richelieu. Historically, the ministériat was unquestionably a time of transition between the domestic government of a king surrounded by his family and the personal government of an absolute monarch ([66], p. 201; [78]). However, was it legal or even legitimate with regard to the theory on the monarchy? This is exactly the question raised by the writings of Morgues and Marillac. Far from being favourably disposed to a return to a limited monarchy, the dévots wanted to proceed directly to the king's personal government without any transition. They defended this absolute government by presenting an actual theory on absolute monarchy. Morgues and Marillac based the sovereign power of the king on principles interpreted in such a way as to exclude all competing powers and, in particular, the excessive power wielded by Richelieu. In this manner, they defended the absolutist version of the theory of the mystical body of the king, which would preclude the assemblées d'États from claiming to represent the kingdom, as it made the king the sole representative of the nation ${ }^{15}$ [79]. They also adhered to the

14 Those findings have been extensively presented and discussed in a book manuscript entitled La pensée politique des dévots Mathieu de Morgues et Michel de Marillac: une opposition au ministériat du cardinal de Richelieu. This monograph has been accepted for publication pending the allocation of a publication grant. What follows is a résumé of its conclusions.

15 “Cependant, on a remarqué en quelques magistrats des fausses generosités [...] qui sous pretexte de corriger quelques manquements, voudroient entreprendre de mettre en compromis l'authorité du royale, qui les a créés et les conserve. 
doctrine of the divine right of kings, explaining that absolute obedience to the king is one of God's commandments, which is why it brooks no exceptions ${ }^{16}$ [80]. For the dévots, the source of this commandment was the Scriptures, in contrast with Richelieu, who came to it through the natural light of reason [81]. Yet, the political doctrine of the divine right of kings was not only a means with which to exclude the competition of internal powers, such as the Protestant State, or external powers, such as the emperor or the pope. The utilitarian, indeed, Machiavellian vision of this doctrine, which renders a sovereign power totally independent, detached even from religion, was outdated. The dévots' interpretation of it is a further demonstration of this very point. Thus, it no longer makes sense to question whether the king's responsibility in front of God is a limit on sovereign power, because this power is no longer defined as totally independent of God or exclusively temporal. In the modern era, the sovereign power did not become lay but, on the contrary, defined itself in terms of its limits inherent to the spirit of the monarchy. Thus, the subjects' right to remonstrance in accordance with justice, the fear of God and the respect for religious principles are intrinsic characteristics of the sovereign power. Nevertheless, respecting religious principles does not mean that the king had to adhere to the Church's interpretations of them. The king was free to exercise his temporal power of divine rights in complete independence of Rome. In case of tyranny, the dévots did not recognize the pope's power to release subjects from their duty of loyalty, while very diplomatically acknowledging the spiritual sovereignty of the Holy Father, so as not to risk creating a schism with Rome. They therefore exhibited a moderate Gallicanism or Catholicisme d'État, rather than an ultramontanism ${ }^{17}$ ([41], p. 9; [82]; [14], p. 55).

Partisans of the absolute monarchy, the dévots did not support the ministerial regime, which they viewed as a theoretical usurpation of sovereign power. Defined as follows in the Testament Politique: "If it's true that the monarchical government more closely resembles that of God than any other, and if the sovereign cannot or does not himself wish to keep an eye on his map and on his compass, reason has him bestowing the responsibility on one particular individual above all others”18 ([81], p. 229); the ministériat appeared as abhorrent to the dévots, as it did to the absolute monarchs, Louis XIV and Louis XV. From the beginning of his personal government in 1661, Louis XIV made the decision to

Comme il est a desirer que la Cour ne rejette jamais, et mesme aime les remonstrances, on doit aussi souhaiter que ceux qui les peuvent faire ne les convertissent pas toujours en plaintes, et jamais en faction, mais en propositions d'expediens [...] le malade mourra certainement si les medecins empoisonnent les remedes."

16 "Finalement, vous ne doutez pas que vous ne soyez dans une monarchie ancienne, establie sur des loys certaines, justes et raisonnables, et qui est gouvernée par un Roy, lequel ne vous a pas conquis par force pour vous posseder avec violence, mais qui nous est donné du ciel.”

17 Mathieu de Morgues: "Le grand Pretre sera assis sur son trosne et le Roy sur le sien, et la paix sera entre eux deux, leurs juridictions sont distinctes, aussi bien que leurs Couronnes sont diverses.” Michel de Marillac: "Nos roys sont defenseurs de l'Eglise, les biens de laquelle et les serviteurs de Dieu sont en leur protection. Ainsy, l'Eglise de son coté, prenant soin des Roys, prie Dieu continuellement pour eux et a toutes les heures presque, elle lève les mains a Dieu pour leur prosperité.” In the same vein, Yves-Marie Bercé maintains that Marillac was not totally ultramontane, but rather concerned with the interests of the Church of France and the Holy See.

18 "S'il est vrai que le gouvernement monarchique imite plus celui de Dieu qu'aucun autre, si le souverain peut ou ne veut pas lui-même avoir l'œil sur sa carte et sa boussole, la raison veut qu'il en donne particulièrement la charge à quelqu'un par-dessus tous les autres.” 
ban the ministériat ${ }^{19}$ [83]. This was an aversion that he intended to pass along to the kings who would succeed him ${ }^{20}$ [84]. Current historiography tends to relativize the role that Richelieu played in implementing absolutism by insisting on the fact that he was under the supervision of the king. In his work, Louis XIII, the Just, Lloyd Moote paints a completely new portrait of the king, a monarch with strong views concerning royal majesty, his subjects' duty of obedience, and the absolute nature of his power. He held the reins of government, listening to advice from one side, the Queen Mother Marie de Médicis, and then, the other, Richelieu, before making a decision. His way of governing was moreover guided by opinions that he had developed long before the arrival of Richelieu: an aversion to the Spanish, a horror of duels and an opposition to the Huguenot state. This leads Moote to observe that in his role as advisor, Richelieu had only to follow the king's own inclinations [9]. Françoise Hildesheimer also insists on the fact that, in the ministériat, the principal ministre is simply an advisor who receives his power from God's chosen one, the king, and exists only through him [25]. As for Christian Jouhaud, he notes that the position of principal ministre creates nothing other than an eminent servant to the king, a private advisor to the prince, his favourite, without any real status ([26], p. 72). This is why Jean-Christian Petitfils argued against the notion of a "duumvirate”, used notably by Robin Briggs, as it implies the sharing of a similar type of power [85]. In Briggs's defence, his reasoning attempts to discern the mutual dependence of the king and his principal ministre; he does not deny the tutorial aspect of the relationship between Richelieu and Louis $\mathrm{XIII}^{21}$ ([62], p. 82). Other historians go even farther: Richard Bonney, David Sturdy and Alan James reject the idea that there had been a "révolution ministérielle", thus contradicting the previously held position that viewed the ministériat as a new system of government, based on the way in which Richelieu presented it in his Testament politique. These authors advance the idea that Richelieu and Mazarin never intended to create a new mode of government, a concept more readily attributable to the interpretation of historians a posteriori. Their only goal was to restore the authority of the king, and to do so, they relied on the existing structures, notably, political patronage. This is why Bonney, Sturdy and James describe the cardinal-ministers' program as conservative. Thus, the fact that Louis XIV decided to govern without a principal ministre in 1661 was not, in their opinion, due to a principled opposition to the ministériat [86-88]. The Bourbon kings wanted to implement absolutism and govern personally, which did not prevent them from using the surrounding power of their close allies, even that of a principal ministre, if the occasion should arise. If Louis XIV did not appoint a principal ministre, it was because there was no one to assume such a function. Thus, James suggests that the 1661 decision be seen rather as the perfection of the ministériat, in the sense that the function was exercised directly by the king. The cardinal-ministers were trusted confidants and helped the kings restore their authority to the point where Louis XIV was able to govern

19 “Ne point prendre de premier ministre, rien n'étant plus indigne que de voir d'un côté toute la fonction, et de l'autre le seul titre de roi."

20 He advised his grandson, Phillip V: “Je finis par un des plus importants avis que je puisse vous donner. Ne vous laisser pas gouverner, soyer le maître, n'ayez jamais de favori ni de premier ministre. Ecoutez, consultez votre conseil, mais décidez. Dieu qui vous a fait roi vous donnera toutes les lumières qui vous seront nécessaires.”

21 Robin Briggs: "In some ways we might see the 'duumvirate' as a highly developed tutorial relationship, but there were additional benefits for the cardinal. If the king took decisions after having the pros and cons laid out for him, then he shared the responsibility for failure; furthermore, opposition to policies established in this way was direct opposition to the monarch himself." 
on his own [89-92]. This way of perceiving the ministériat, from the point of view of what it had historically been, partly explains why not a single study, even the most recent, considers de Morgues's criticisms as a criticism of the ministériat ([1], p. 175; [11], p. 185; [85], p. 613). At this point, it seems important to distinguish between what the ministériat actually was and how it was perceived by its contemporaries, including both the cardinal-ministers and their adversaries [93].

Wishing to preserve the absolute power of the monarchy, the dévots proposed that the king would be advised by a council limited to four or five councillors, selected according to wisdom rather than status. Moreover, Marillac did not insist on the inclusion of the chancellors or the garde des sceaux in the smaller council, but subjected them to the same regulations as anyone else: they were included when the king called upon them ${ }^{22}$ [59]. It was quite the opposite when it came to Richelieu, as he was not subject to the same criteria. Anxious in temperament, the cardinal often let himself be guided by a feeling for the precariousness of his situation ${ }^{23}$ [94], which led him to devise a theory, creating a new institution that would assure him of certain stability. Contrary to the spirit of the monarchy, the ministériat altered the direction of the government by Grand Conseil through the institutionalization of an assistant to the king. Morgues fought for the implementation of a monarchy based strictly on the divine rights of the king: "God wishes you to reign justly and wisely in peace without the assistance of this man." 24 [95]. Naturally, principal ministre Richelieu denied he wanted anything other than justice and charity, but as laudable as his intentions were, it was not up to him to decide what policies to pursue throughout the kingdom. Far from being in favour of a monarchy limited by Parlement or the États généraux, Mathieu de Morgues and Michel de Marillac were therefore absolutists.

There is further evidence concerning the dévots' absolutism: their support for the appointment of intendants in the provinces to ensure the correct application of the sovereign's will ([57], pp. 241-42, 250-51). Similarly, their opposition to the chambres de justice established by Richelieu does not attest to the judicial sovereignty of the Parlements, but rather, their rejection of any sharing of the king's right to judge ${ }^{25}$ [96]. Furthermore, the dévots' thinking demonstrates that the absolute State did not turn into an État de finance, but remained an État de justice, the aim of which was to establish charity on Earth. Their opposition to the Protestant rebellions once again shows their attachment to the absolute monarchy ${ }^{26}[97,98]$, even though Morgues was at a loss to justify the civil insurrection of the king's mother and brother. Yet, even in this difficult exercise, Morgues remained true to his ideas and

22 “Outre lequel Conseil, il est bienvenu que le prince aye un petit nombre de ceux mesme dudit Conseil jusqu'à trois ou quatre ou bien peu plus au lequel Conseil Secret. Il est bon qu'il examine les conslusions dudit Conseil Ordinaire, car telle chose pouvoit avoir esté advisées par la plus grande opinion dudit Conseil Ordinaire qui ne seroit pas la meilleure."

23 Françoise Hildesheimer notices that Richelieu was driven by the need to remain in power.

24 "Dieu vous veut faire régner avec paix, justice et sagesse sans l'assistance de cet homme."

25 “La justice, par laquelle seule les Roys regnent vraiment absolus aura des ministres incorruptibles sur lesquels la passion, l'amour, la haine, l'argent ni l'avarice n'auront nulle puissance pour envelopper l'innocent avec le coupable. La rigueur de la loy sera temperée par votre clemence, le repentir et les larmes du criminel estant quelquefois acceptés pour supplice et chastiment de son delit."

26 "Vous voulez que nous reprenions les armes pour achever ce qui a esté bien avancé, mais vous ne savez pas si nous pratiquons des meilleurs moyens que ceux que vous mettez en avant pour avoir les ames sans tuer les coprs et estre maistres des villes sans y entrer par la breche.” 
explained that members of the royal family rebelled in order to preserve their dignity and not as a claim to share in the exercise of sovereign power $^{27}$ ([96], p. 16).

It does not therefore appear that the thinking of the dévots and that of Richelieu were in such great conflict over one side supporting an absolutist regime and the other a limited monarchy. The real disagreement between the two parties was instead related to the cardinal-minister's desire to be the king's sole advisor. Altering the nuanced opinions of those he considered adversaries, the cardinal ultimately prevailed. The last act of that conflict unfolded around the question of Europe. Although the dévots' only advice was to avoid breaking diplomatic relations, even in time of war, in order to provide France with a decisive position in Christendom ${ }^{28}$ [99,100], the cardinal claimed that the dévots sought peace at any price, so as not to undermine the interests of Hapsburg Spain, alone capable of restoring Christianity. To remain in power, Richelieu thought it right to advocate continuing the war regardless of the consequences, a view he would regret several years later in his Testament politique [101].

\section{Conclusions}

For several decades, the historiography has presented the dévots in the same way that Richelieu, their adversary, portrayed them. However, can one rely on the way in which someone is portrayed by an adversary, particularly in the realm of politics? After a careful consideration of all the relevant information, it appears that the dévots, contrary to the commonly held theory, did not defend the model of the limited monarchy. On the contrary, like Richelieu, Mathieu de Morgues and Michel de Marillac, they were absolutists.

\section{Acknowledgments}

The author is gratetul to Richard Lebeau for translating this article.

\section{Conflicts of Interest}

The author declares no conflict of interest.

27 “Les ennemis de la Royne sont obligés de montrer en elle la folie ou le vice. Mais je crains fort qu'ils ne vous veuillent oster une aide [...] d'ou je tire ma première conclusion: la Royne votre mere n'ayant jamais rien fait qui lui puisse apporter le moindre blasme [...] Quand votre Majesté lui voudroit oster la connoissance des affaires de son royaume, vous ne pouvez en conscience la priver de votre presence."

28 Mathieu de Morgues: "Pour effacer cette calomnie, je prie tres humblement votre Majesté de se souvenir que la Royne votre mere a esté presente a tous les conseils qui ont esté pour les affaires d'Italie et qu'elle a esté toujours d'advis qu'il fallait la garder d'oppression, secourir Monsieur de Mantoue et arrester le cours de la conqueste de vos ennemis." Richelieu: "Pour raison de quoi nous avons fait mettre sous une grande et puissante armée composée la conduite et commandement a une personne (le cardinal de Richelieu) qui sache dignement s'en acquitter et en qui nous nous puissions reposer d'une affaire de si grande consequence [...] Lui donner en outré plein pouvoir et puissance de recevoir et ouïr toutes manieres d'ambassadeurs, de Princes, villes, communautéès, seigneuries, potentats, particuliers, leur en envoyant ou renvoyer selon l'estat des affaires et ainsi qu'il appartiendra: faire et traiter paix, trècesm ligues offensives et defensives et tout autre traié que besoin sera avec tous Roys, Princes, potentats et Republiques.” 


\section{References and Notes}

1. Laurent Avezou. "Richelieu vu par mathieu de morgues et paul hay de chastelet." Travaux de littérature 18 (2005): 167-78.

2. Donald A. Bailey. "Power and piety: The religiosity of michel de marillac." Canadian Journal of History/Annales Canadiennes d'Histoire 42, no. 1 (2007): 1-24.

3. Donald A. Bailey. "Introduction." In Nicolas Lefevre sieur de Lezeau. La vie de Michel de Marillac (1560-1632). Garde des sceaux sous Louis XIII. Transcribed and edited by Donald A. Bailey. Quebec: Les presses de l’Université Laval, 2007, pp. XXV-LXX.

4. Jean-Vincent Blanchard. Éminence Cardinal Richelieu and the Rise of France. New York: Walker \& Company, 2011, pp. 109-29.

5. James B. Collins. The State in Early Modern France, 2nd ed. New-York: Cambridge University Press, 2009, pp. 36-70.

6. Seung Hwi Lim. “Mathieu de Morgues, bon français ou bon catholique?” XVIIème Siècle 213 (2001): 655-72.

7. Alan James. The Origins of French Absolutism 1598-1661. Edinburg: Pearson Education, 2006, p. 136.

8. Robert J. Knecht. Richelieu. New York: Longman, 1991, pp. 31, 88-89, 170-72, 178.

9. Lloyd Moote. Louis XIII, the Just. London: University of California Press, 1989, pp. 199-217.

10. Stéphane-Marie Morgain. "La disgrâce de Michel de Marillac." Histoire et Archives 7 (2000): 49-69.

11. Stéphane-Marie Morgain. "Richelieu, un chrétien en politique? L’opinion de Mathieu de Morgues.” Richelieu, de l'évêque au Ministre. Edited by Françoise Hildesheimer and Laurent Avezou. La Roche-sur-Yon: Recherches Vendéennes, 2009, vol. 16, pp. 179-212.

12. Donald A. Bailey. “The Family and Early Career of Michel de Marillac (1560-1632).” In Society and Institutions in Early Modern France. Edited by Mack P. Holt. Athens, Georgia: U. Georgia Press, 1991, pp. 170-89.

13. Seung Hwi Lim. "La pensée politique des "bons catholiques” dans la première moitié du XVIIème siècle.” Doctoral thesis in History, University of Pari-Sorbonne, France, 1998, 389-458.

14. Yves-Marie Bercé. Les Monarchies Espagnoles et Française du Milieu du XVIème Siècle à 1714. Paris: Sedes, 2000, p. 55.

15. Yves Durand. "Mystique et Politique au XVIIème siècle: L’influence du Pseudo-Denys." XVIIème Siècle 173 (1991): 326.

16. Russell J. Major. Representative Government in Early Modern France. New Haven: Yale UP, 1980.

17. Joseph Bergin. "Richelieu and his bishops? Ministerial Power and Episcopal Patronage under Louis XIII.” Richelieu and his Age. Edited by Joseph Bergin and Laurence Brockliss. Oxford: Clarendon Press, 1992, pp. 175-202.

18. Hélène Duccini. Faire Voir, Faire Croire. L'opinion Publique Sous Louis XIII. Paris: Champ Vallon, France, 2003, pp. 453-54. 
19. Georges Pagès. “Autour du grand orage. Richelieu et Marillac: Deux politiques.” Revue Historique 179 (1937): 63-97.

20. Caroline Maillet-Rao. "La théologie politique des dévots Mathieu de Morgues et Michel de Marillac, opposants au cardinal de Richelieu.” Renaissance and Reformation/Renaissance et Réforme 32, no. 3 (2009): 51-77.

21. Caroline Maillet-Rao. "Mathieu de Morgues and Michel de Marillac: The dévots and absolutism.” French History 25, no. 3 (2011): 279-97.

22. Cf: Richelieu. Sur les brouilleries a la Cour de France entre la Royne Mère, la reine son épouse et M. Gaston son frère d'une part et du Cardinal de Richelieu son premier ministre. In Papiers de Richelieu. A.A.E., mem. and doc., France. Vol. 795 bis, fo. 324 to 381; published under the title Journal de M. le Cardinal duc de Richelieu, qu'il a fait durant le grand orage de la cour en l’année 1630 1631, tirés de ses mémoires qu’il a écrits de sa main.

23. Georges Mongrédien. La journée des Dupes: 10 Novembre 1630. Collection Les Trente Journées qui ont fait la France. Paris: Gallimard, 1961.

24. Jean-François Dubost. Marie de Médicis. La Reine Dévoilée. Paris: Éditions Payot et Rivages, 2009, pp. 744-56.

25. Françoise Hildesheimer. Richelieu. Paris: Flammarion, 2004, pp. 230-31.

26. Christian Jouhaud. La main de Richelieu ou le Pouvoir Cardinal. Paris: Gallimard, 1991, pp. 52-53.

27. Robert Knecht. Richelieu. New-York: Longman, 1991, pp. 34-40.

28. Lloyd Moote. Louis XIII, the Just. California: University of California Press, 1989, pp. 199-219.

29. Roland Mousnier. L'Homme Rouge. Paris: Robert Laffont, 1992, pp. 381-90.

30. Victor L. Tapié. La France de Louis XIII et Richelieu. Paris: Flammarion, 1967, pp. 219-22.

31. Robert Merle. Complots et Cabales. Paris: De Fallois, 2001.

32. William Beik. A Social and Cultural History of Early Modern France. New York: Cambridge University Press, 2009, pp. 190-200.

33. Henri Brémond. Histoire Littéraire du Sentiment Religieux. Paris: Armand colin, 1967 (1st ed. 1923), vol. 2, pp. 193-262.

34. Etienne Thuau. Raison d'Etat et Pensée Politique à l'époque de Richelieu. Paris: Armand Colin, 1966.

35. Stéphane-Marie Morgain. La théologie politique de Pierre de Bérulle (1598-1629). Paris: Publisud, 2001.

36. Jean-Pierre Gutton. Dévots et Société au XVIIieme Siècle. Construire le Ciel sur la Terre. Paris: Belin, 2004, p. 219.

37. Sylvio Franceschi Hermann. "La génèse du catholicisme d’État et son aboutissement au début du ministériat de Richelieu: Les cathliques zélés à l’épreuve de l'affaire Santarelli et la clotûre de la controverse autour du pouvoir pontifical au temporal (1626-1627).” Annuaire-bulletin de la Société de l'histoire de France Volume (Année 2001): 19-53.

38. Mathieu de Morgues. Les deux faces de la vie et de la mort de Marie de Médicis: Royne de France, Veuve de Henri IV, mere de Louis XIII roi très chrestien: Discours funèbre. Anvers, 26 February 1643, p. 4. 
39. Arrest de la chambre de l'Arsenal contre Mathieu de Morgues, abbé de saint-Germain. Extrait des registres de la chambre de justice établie par le roy en son château de l'Arsenal à Paris, automne 1631, B.N.F., Ms. Fr., n.a.f., 7316.

40. Mathieu de Morgues. Recueil des diverses pièces pour servir a la défense de la royne-mère du roi très-chrétien Louis XIII. Anvers, 1937, tome I, 496 p., tome II, 422 p.

41. Mathieu de Morgues. Antirrhopon ou Contrepoids aux jésuites et aux ministres de la religion pretendue reformée. Printed in France, 1617, 24 p.

42. Hélène Duccini. "Regard sur la littérature pamphlétaire en France au XVIIème siècle.” Revue Historique 260 (1978): 315.

43. Hubert Carrier. "Conclusion. Pour une Définition du Pamphlet: Constantes du Genre et Caractéristiques Originales des Textes Polémiques du XVIème Siècle.” In Le Pamphlet en France au XVIème Siècle. Actes d'un Colloque Organisé par le Centre V.L. Saulnier. Paris: École Normale supérieure de jeunes filles, 1983.

44. Christian Jouhaud. "Les Écrits Polémiques.” In Histoire de la France Littéraire. Classicismes XVIIe - XVIIIeme Siècle. Edited by Jean-Charles Darmon and Michel Delon. Paris: PUF, 2006, vol. 2, pp. 732-61.

45. Christiane de Morgues. "Pamphlets et contraintes d'expression. Autour de la Très-humble, trèsvéritable et très-importante remontrance au roi de Mathieu de Morgues.” Cahiers de la HauteLoire 153 (1995): 153.

46. Gustave Fagniez. "Mathieu de Morgues et le procès de Richelieu.” Revue des Deux Mondes Volume 162 (décembre 1900): 561-63.

47. Maximin Deloche. Autour de la plume du cardinal de Richelieu. Paris: Société française d'imprimerie de et librairie, 1920, pp. 354 et 472.

48. Michel de Marillac. De la ligue et particulièrement comme pendant icelle il a esté le premier qui a fait la proposition sur laquelle est intervenue arrest pour avoir un roy catholique et français, et empescher que la couronne fust transferée en main etrangère au prejudice de la loy salique. In Nouvelle collection des mémoires pour servir à l'histoire de France. Edited by MM. Michaud et Poujoulat. Paris: Éditeur du commentaire analytique du code civil, 1838, t. XI, 541-48.

49. Donald A. Bailey, “Saint Louise de Marillac’s uncle: Louis XIII’s Garde des Sceaux, Michel de Marillac (1560-1632).” Vincentian Heritage Journal 30, no. 2 (2010): 91-104.

50. Yves-Marie Bercé. “Michel de Marillac.” In Dictionnaire du Grand Siècle. Edited by François Bluche. Paris: Fayard, 1990, pp. 975-76.

51. Edouard Éverat. Michel de Marillac, sa vie, ses œuvres. Riom: Ulysse Jouvet, 1894, 209 p.

52. Nicolas Lefèvre de Lezeau. La vie de Michel de Marillac (1560-1632). Garde des sceaux sous Louis XIII. Transcribed and edited by Donald A. Bailey. Québec, Canada: Les Presses de l’Université Laval, 2007, 653 p.

53. Louis-Gabriel Michaud. Biographie Universelle Ancienne et Moderne. Paris: L. G. Michaud Librairie-éditeur, 1860, vol. XXVI, 660-61.

54. Louis Jean Nicolas Monmerqué. "Notice sur Michel de Marillac.” In Collection Complète des Mémoires Relatifs à l'histoire de France. Edited by Claude-Bernard Petitot. Paris: Foucault 1826, vol. XLIX, pp. 441-44. 
55. Louis Moréri. Le Grand Dictionnaire Historique. Genève: Slatkine reprints 1995 (1st ed. 1759), vol. VII, pp. 253-54.

56. Yves Durand. L'ordre du Monde: Idéal Politique et Valeurs Sociales en France du XVI au XVIII Siècle. Paris: Sedes, 2001, p. 108.

57. Michel de Marillac. Ordonnance sur les Plaintes des Estats assemblés a Paris en 1614, et de l'assemblée des Notables Reunis a Rouen, en 1617 et 1626. In Recueil général des anciennes lois françaises, depuis l'an 420 jusqu'à la Révolution de 1789. Edited by FrançoisAndré Isambert. Paris: Belin-Leprieur, 1829, vol. XVI, pp. 223-344.

58. Michel de Marillac. Memoire dressé par le garde des sceaux de Marillac principalement contre l'authorité du Parlement. BNF, Ms. Fr. 75-49, f 1-f 128.

59. Michel de Marillac. Traité du Conseil du Roy. AN, U 955 a, f॰1-f59.

60. Michel de Marillac. Traité des chanceliers et gardes des sceaux de France. AN, U 948, f²r-4r.

61. François Olivier-Martin. L'absolutisme Français. Paris: LGDJ, 1997, p. 338. Republication of courses given in 1950-1951.

62. Robin Briggs. "Richelieu and Reform: Rhetoric and Political Reality.” In Richelieu and His Age. Edited by Joseph Bergin and Laurence Brockliss. Oxford: Clarenton Press, 1992, pp. 71-97.

63. Friedrich Meinecke. L'idée de la Raison d'Etat Dans l'histoire des Temps Modernes. Genève: Droz, 1973. 1st ed. 1926, p. 1924.

64. Joël Cornette. L'affirmation de l'Etat Absolu 1492-1652. Paris: Hachette, 2000. 1st ed. 1992, p. 223.

65. Jean-François Courtine. "L’héritage Scolastique Dans la Problématique Théologico-Politique de l’âge Classique.” In L'Etat Baroque. Edited by Henry Mechoulan. Paris: Vrin, 1985, p. 98.

66. Françoise Hildesheimer. Du Siècle d'or au Grand siècle, L'Etat en France et en Espagne, $X V I^{e}-X V I I^{e}$ Siècle. Paris: Flammarion, 2000, p. 83.

67. Fanny Cosanday, and Robert Descimon. L'absolutisme en France: Histoire et Historiographie. Paris: Seuil, 2002, pp. 94-104.

68. Jean Bérenger. "Le conflit Franco-Espagnol et la guerre du Nord." In Guerre et paix dans l'Europe du XVII ème siècle. Edited by Lucien Bély, Jean Bérenger and Alain Corvisier. Paris: Sedes, 2001, vol. I, p. 313.

69. Françoise Hildesheimer. “Au cœur religieux du ministériat. La place de Dieu dans le testament politique de Richelieu.” Revue d'Histoire de l'Eglise de France 84 (1998): 21.

70. Roland Mousnier. “Conclusion Générale.” In Richelieu et la culture. Actes du Colloque international en Sorbonne. Edited by Roland Mousnier. Paris: CNRS, 1987, p. 225.

71. Jean de Viguerie. “Richelieu théologien.” In Richelieu et la Culture. Paris: CNRS, 1987, p. 34.

72. Orest Ranum. "Richelieu, L’histoire et les Historiographes.” In Richelieu et la Culture. Paris: CNRS, 1987, p. 127.

73. Hermann Weber. "Richelieu Théoricien Politique.” In Richelieu et la Culture. Paris: CNRS, 1987, pp. 58-59.

74. Jörg Wollenberg. Les Trois Richelieu. Servir Dieu, le roi et la Raison. Paris: François-Xavier de Guibert, 1995. 1st ed. 1977. 
75. Armand Jean du Plessis, cardinal duc de Richelieu. Oeuvres Théologiques. Paris: Honoré Champion, 2002.

76. Pierre Blet. Richelieu et l'Église. Versailles, France: Via romana, 2007.

77. Richard Bonney, and King's Debts. Finance and Politics in France 1589-1661. Oxford: Clarendon Press, 1981, p. 145.

78. Orest Ranum. Les créatures de Richelieu. Paris: Éditions A. Pédone, 1966, pp. 27-45.

79. Mathieu de Morgues. Bons avis sur plusieurs mauvais avis. 1650, p. 20.

80. Mathieu de Morgues. Le droict du Roy sur des sujets chrestiens. 1622, p. 31.

81. Richelieu. "Qui Montre que la Raison Doit Estre la Regle et la Conduite d'un Estat.” In Testament Politique de Richelieu. Édité par Françoise Hildesheimer. Paris: Honoré Champion, 1995, p. 245.

82. Michel de Marillac. Examen du livre: Remontrance et conclusions des Gens du Roy et Arrests de la Cour de Parlement du 26 novembre 1610, attribué faussement à M. Servin conseiller du Roy en son conseil et son avocat en la cour de Parlement de Paris, comme ayant esté fait en ladite Cour sur le livre du Cardinal Bellarmin: Pour montrer les ignorances, impertinences, faussetés et prevarications qui se trouvent presque en toutes les pages. 1611, pp. 12-17.

83. Arthur de Boislisle. Les Conseils du roi Sous Louis XIV. Geneva: Slatkine Reprints, 1977. 1st ed. 1884, p. 71.

84. Michel Antoine. Le Conseil du roi Sous le règne de Louis XV. Paris/Genève: Droz, 1971, p. 28.

85. Jean-Christian Petitfils. Louis XIII. Paris: Perrin, 2008, pp. 610-13.

86. Ernest Lavisse. Histoire de France. Louis XIV. Paris: Tallandier, 1978, tome 1, pp. 147-48.

87. Laurence Brockliss. "The anatomy of the Minister-Favourite." The World of the Favourite. Edited by John H. Elliott and Laurence Brockliss. New Haven: Yale University Press, 1999, pp. 279-309.

88. Marc Fumaroli. "Nicolas Fouquet, the Favourite Manqué.” The World of the Favourite. Edited by John H. Elliott and Laurence Brockliss. New Haven: Yale University Press, 1999, pp. 239-55.

89. Richard Bonney. “Absolutism: What'S in a Name?” The Limits of Absolutism in Ancien Regime France. Edited by Richard Bonney. Aldershot: Variosum, 1995, pp. 93-117.

90. Richard Bonney. "Was there a Bourbon Style of Government?” The Limits of Absolutism in Ancien Regime France. Aldershot: Variosum, 1995, pp. 161-77.

91. Alan James. The Origins of French Absolutism 1598-1661. London: Pearson Education Limited, 2006, pp. 85-95.

92. David J. Sturdy. Richelieu et Mazarin. Basingstoke: Palgrave Macmillan, 2004, pp. 149-60.

93. Giuliano Ferreti. "Élites et peuples à Paris, 1642-1650. La naissance de l'historiographie sur Richelieu.” Nouvelles de la république des lettres 1 (1997): 106.

94. Françoise Hildesheimer. Relectures de Richelieu. Paris: Publisud, 2000, p. 152.

95. Mathieu de Morgues. Le génie démasqué. In Recueil des diverses pièces pour servir a la défense de la royne-mère du roi très-chrétien Louis XIII. Anvers, 1937, tome I, p. 454.

96. Mathieu de Morgues. Consolation aux bons Français. Paris, 1618, p. 27.

97. Mathieu de Morgues. Advis d'un theologien sans passion. Paris, 1626, pp. 42-43. 
98. Michel de Marillac. Discours sur le bon Gouvernement. Archives des affaires étrangères, France, Correspondance, 10 June 1630, vol. 792, f 213 r.

99. Mathieu de Morgues. Tres humble remontrance au Roy. In Recueil des diverses pièces pour servir a la défense de la royne-mère du roi très-chrétien Louis XIII. Anvers, 1937, tome I, p. 53.

100. Lettres-patentes par lesquelles le Roy nomme le cardinal de Richelieu pour commander ses armées avec un plein pouvoir. Archives des affaires étrangères, France, Correspondance, f 321.

101. Françoise Hildesheimer. “Guerre et paix selon Richelieu.” In L'europe des Traités de Westphalie. Edited by Lucien Bély. Paris: Presse Universitaire de France, 2000, p. 49.

(C) 2013 by the author; licensee MDPI, Basel, Switzerland. This article is an open access article distributed under the terms and conditions of the Creative Commons Attribution license (http://creativecommons.org/licenses/by/3.0/). 